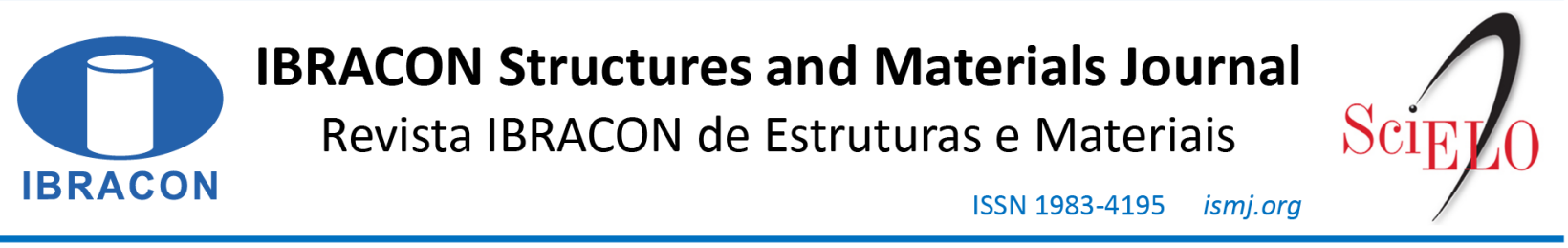

ORIGINAL ARTICLE

\title{
Global analysis of DEF damage to concretes with and without fly-ash
}

\section{Análise global dos danos da DEF em concretos com e sem cinza volante}

\author{
Nicole Pagan Hasparyk ${ }^{\mathrm{a}}$ (D) \\ Dioice Schovanz ${ }^{\mathrm{b}}$ (D) \\ Francieli Tiecher ${ }^{\mathrm{b}}$ (i) \\ Selmo Chapira Kuperman ${ }^{\mathrm{c}}$ (D)
}

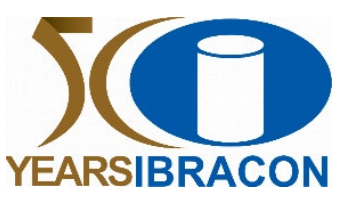

${ }^{a}$ Furnas Centrais Elétricas S.A., Departamento de Segurança de Barragens e Tecnologia, Goiânia, GO, Brasil

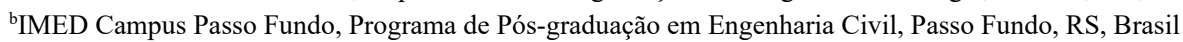

${ }^{\mathrm{c} D e s e k ~ L t d a ., ~ S a ̃ o ~ P a u l o, ~ S P, ~ B r a s i l ~}$

Received 15 February 2021

Accepted 01 October 2021

\begin{abstract}
Delayed Ettringite formation (DEF) is an internal expansive reaction that can damage concrete. $\mathrm{DEF}$ is strongly influenced by the temperature, above about $60-65^{\circ} \mathrm{C}$, and other factors involving cement chemistry especially, but also its physical characteristics. The exposure environment over time also promotes a condition to increase deterioration from DEF. Expansions results from secondary ettringite formation are progressive and can lead concrete to microcracking impacting its performance and durability over time. Several concrete structures are pointed to be severely attacked by DEF, and test method as well a better comprehension on this pathology is necessary to promote specific and proper preventive measures to avoid future damages. Furthermore, compared to alkali-silica reaction, DEF occurs more readily and aggressively, and sometimes prematurely, depending on several factors, such as type of cement, concrete mix design, exposure conditions, among others. This paper involves an overall analysis of the behavior of concretes with two types of Portland cements (High early-strength cement and a Portland pozzolanic cement, with fly-ash) in relation to DEF process. Several data from a laboratory study where DEF was induced through a specific thermal curing procedure are presented and discussed. The analyses involved the assessment of physical, mechanical, and expansive properties besides microstructural monitoring of samples from concretes over time. These experiments allowed detecting high values of expansions from DEF (up to $1.2 \%$ ) in the concrete without fly ash. The mechanical properties were severely impacted from this deleterious process; as expansions increased, losses in the mechanic and elastic properties were verified. Expansion levels in the order of $0.5 \%$ prompted remarkably high reductions and, at about $1 \%$ the losses were relevant for both strengths (tensile and compressive) and modulus of elasticity, of $60 \%$ and $80 \%$, respectively, in the presence of cement without fly-ash. Concrete microstructure has indicated massive formations of ettringite as well as micro-cracking and the fragility of the cement matrix because of DEF. On the other hand, expansion up to $0.2 \%$ did not promote important negative effects on the properties of concrete, especially with the pozzolanic cement tested. Furthermore, an overall approach with several correlations between physical and mechanical properties was taken to obtain different levels of deterioration for a concrete presenting DEF.
\end{abstract}

Keywords: concrete, delayed ettringite formation (DEF), expansion, mechanical and physical properties, microstructure, fly-ash, damage.

Resumo: A formação da etringita tardia (DEF) é uma reação expansiva que ocorre no interior do concreto já endurecido, podendo danificá-lo. A DEF é fortemente influenciada pela temperatura, quando acima de 60$65^{\circ} \mathrm{C}$, e outros fatores envolvendo a química do cimento, principalmente, características físicas e os materiais constituintes do cimento. $\mathrm{O}$ ambiente de exposição ao longo do tempo também promove uma condição propícia para aumentar a deterioração por DEF. As expansões resultantes da formação da etringita tardia são progressivas e podem levar o concreto a microfissuras, afetando seu desempenho e durabilidade ao longo do tempo. Diversas estruturas de concreto são apontadas como severamente atacadas por DEF, sendo necessário

Corresponding author: Nicole Pagan Hasparyk. E-mail: nicole@furnas.com.br

Financial support: This work had financial and infrastructure support from Furnas Centrais Elétricas S.A./ANEEL, P\&D 0394-1504-2015. D. Schovanz benefits from a partial scholarship financed by the Research Foundation of the State of Rio Grande do Sul - FAPERGS by the FAPERGS Grant.

Conflict of interest: Nothing to declare.

Data Availability: The data that support the findings of this study are available from the corresponding author, NPH, upon reasonable request. This is an Open Access article distributed under the terms of the Creative Commons Attribution License, which permits unrestricted use, distribution, and reproduction in any medium, provided the original work is properly cited. 
um melhor entendimento desta patologia a fim de promover medidas preventivas específicas e adequadas para evitar danos futuros. Além disso, em comparação com a reação álcali-sílica, a DEF ocorre de forma mais rápida e agressiva, e muitas vezes de modo prematuro, dependendo de vários fatores, como tipo de cimento, concreto, condição de exposição, entre outros. Este trabalho envolve uma análise geral do comportamento de concretos com dois tipos de cimentos Portland (cimento de alta resistência e outro cimento pozolânico, com cinza volante) em relação ao processo DEF. Várias informações de estudo laboratorial são apresentadas e discutidas após a indução de DEF por um procedimento específico com cura térmica. As análises envolveram a avaliação das propriedades físicas, mecânicas e expansivas, além do monitoramento microestrutural de amostras de concretos ao longo do tempo. Esses experimentos permitiram detectar altos valores de expansões de DEF (até 1,2\%), principalmente no concreto sem pozolana. As propriedades mecânicas foram severamente afetadas por esse processo deletério; com o aumento das expansões, foram constatadas perdas nas propriedades. Considerando níveis de expansão da ordem de $0,5 \%$, a redução foi muito elevada e, em cerca de $1 \%$ as perdas foram relevantes tanto para as resistências (tração e compressão) e módulo de elasticidade, de $60 \%$ e $80 \%$, respectivamente, na presença de cimento sem cinzas volantes. A microestrutura do concreto indicou formações maciças de etringita bem como microfissuras e a fragilidade da matriz de cimento como consequências da DEF. Por outro lado, a expansão de até 0,2\% não promoveu efeitos negativos importantes nas propriedades do concreto, principalmente com o cimento pozolânico testado. Além disso, uma abordagem geral com várias correlações entre as propriedades físicas e mecânicas foi feita para obter diferentes níveis de deterioração do concreto por DEF.

Palavras-chave: concreto, formação da etringita tardia (DEF), expansão, propriedades físicas e mecânicas, microestrutura, cinza volante, deterioração.

How to cite: N. P. Hasparyk, D. Schovanz, F. Tiecher, and S. C. Kuperman, "Global analysis of DEF damage to concretes with and without flyash" Rev. IBRACON Estrut. Mater., vol. 15, no. 3, e15305, 2022, https://doi.org/10.1590/S1983-41952022000300005

\section{INTRODUCTION}

Delayed ettringite formation (DEF) involves crystallization of ettringite in hardened cementitious matrix. In the presence of moisture, it can cause progressive expansions over time, leading to cracking. The increase of these expansions can affect the mechanical properties of concrete and accelerate the entry of aggressive agents, causing loss of performance and durability of structures.

DEF occurs when the aluminates are not completely consumed during the cement hydration, being the sulfated phase still present after the first hours of this process [1], [2]. Alterations during hydration process occurs due to high temperature levels, and above $65^{\circ} \mathrm{C}$. The mechanisms of DEF involve dissolution of calcium hydroxide and decalcification of C-S-H prior to ettringite production, according to $\mathrm{Gu}$ et al. [3]. The available aluminum is originated from the monosulfate itself since it is the main source of $\mathrm{Al}_{2} \mathrm{O}_{3}$ in Portland cement [4], [5]. In the early stages of the cement hydration process the characteristics of the cement, are among the main factors interfering in DEF [6], [7]. The use of pozzolanic admixtures can decrease the heat evolution during hydration because they react slower than the clinker [8]. The phases produced in the pozzolanic reaction also led to greater stability, improving the concrete resistance to acid attacks [9].

Nonetheless, the preventive measures involving mineral admixtures is far from conclusive. Several variables from admixtures, such as type, fineness, composition, optimum contents interfere in the mitigative process [10]-[14]. Some results also indicate a non-mitigative behavior for DEF, depending on the material and test method [15], [16].

The probability of DEF occurrence is associated with the amounts of sulfate and aluminum in the cement. If there is too much sulfate and too little aluminum, the sulfoaluminate phase will be ettringite, otherwise, it will be monosulfate [17]. Moreover, specific surface and alkalis play an important role in the DEF occurrence, besides the relation $\left(\mathrm{SO}_{3}\right)^{2} / \mathrm{Al}_{2} \mathrm{O}_{3}$, that is suggested to be below 2 in order to reduce risks of DEF, according to Zhang et al. [14].

The high porosity in the interfacial transition zone (ITZ) due to the wall effect allows the beginning of the ettringite crystallization in this site. The speed of ettringite crystallization is higher compared to the cement matrix, even tough, the pressures generated in the ITZ may be not too high, according to Jebli et al. [18]. The DEF expansion can reach high levels, of the order of $2 \%$ and, according to some researchers it is also possible to detect, in laboratory tests, mass gains as expansions increases achieving levels higher than $1 \%$ due to ettringite crystal precipitations in the matrix [3].

These high levels of expansion affect the modulus of elasticity of concrete, which values can decrease up to $40 \%$ [19]-[21]. Brunetaud et al. [22] point, though, that even smaller expansions, next to $0.10 \%$, can reduce the modulus of elasticity of concrete, which is a mechanical property widely affected by cracking. The reduction in the porosity as DEF fills the voids leads to pressure and cracking, decreasing modulus of elasticity as well as strengths [11]. According to Pichelin et al. [4], there is a latent period between expansions from $0.05 \%$ to $0.10 \%$ in which just the modulus is affected by DEF.

In general, the compressive strength is less sensitive to expansive reactions when compared to the modulus of elasticity. However, many studies have shown that the compressive strength can also be intensely affected by DEF, even increasing at early stages [19], [23], [24]. According to Pichelin et al. [4], this behavior can be explained by 
considering that the secondary ettringite crystallizes in the ITZ. DEF can also fill pre-existing cracks, besides voids. In consequence, it fills and densifies the cement matrix, increasing the compressive strength. However, if there is enough moisture, the DEF spreading speed will be greater than other expansive reactions, such as ASR (Alkali-Silica Reaction), for example [25]-[27]. Hence, there will be growth in expansion and cracking, decreasing the compressive strength, besides having a negative impact in other properties, such as tensile strength and modulus.

After diagnosing DEF-affected concrete structures in the field, many researchers have shown concern for the fact that it is not possible to interrupt the development of the reaction until now [28]-[30], similarly to ASR. The pressure caused by the expansions is affected by structural restraint and the process is like the one caused by ASR [31]. Among the existing gaps, the lack of standardized methods to assess the DEF-potential in laboratory studies can be highlighted. Some researchers have developed their methodologies, however, showing many divergences, such as Melo [32], Giannini et al. [19], Fu [33], Dayarathne et al. [10], Leklou et al. [13], Rashidi et al. [34], Duggan and Scot Test [35], Kchakech et al. [36], Martin et al. [37], Nguyen et al. [38].

In general, to assess concrete structures affected by DEF the properties that have been evaluated are modulus of elasticity, compressive strength, and tensile strength [1], [4], [39], [40]. More recently, two indexes obtained from the Stiffness Damage Test (SDT) have been suggested: The Stiffness Damage Index (SDI) and the Plastic Deformation Index (PDI). This trial was initially employed to assess ASR, but some promising initial results concerning to DEF were obtained [26], [37].

Based on this context, the main purpose of this research is to evaluate the levels of damage of concretes with and without fly-ash when subjected to DEF triggering conditions. The study presents data from several physical, mechanical, and microstructural analyses and correlations to different expansion levels over one year of monitoring.

\section{EXPERIMENTAL PROGRAM}

The mix proportioning adopted in the experimental program was 1:1.6:1.9 (by mass), water-cement $(\mathrm{w} / \mathrm{c})$ ratio of 0.46 , and cement content of $470 \mathrm{~kg} / \mathrm{m}^{3}$. A polyfunctional admixture based on lignosulfonate and polycarboxylate was used in the proportion of $0.6 \%$ and $0.1 \%$ for ASTM cement type III and IP, respectively.

A thermal curing method, based on Fu [33], Kchakech et al. [36], and Rashidi et al. [34], was adapted by increasing the temperature in the first hours of cement hydration to create conditions for DEF occurrence, as shown in Figure 1.

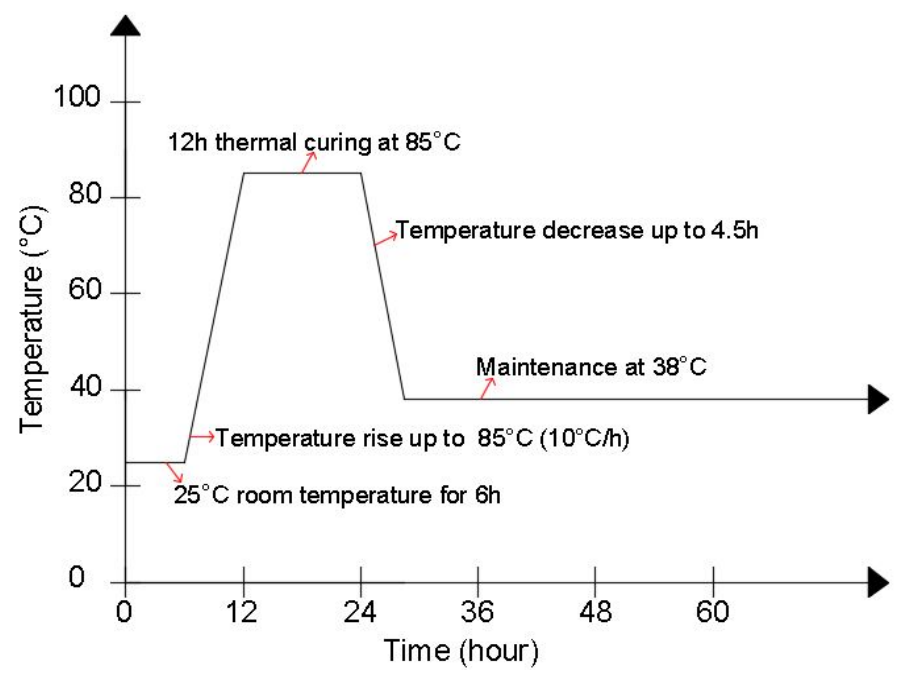

Figure 1. Curing process and environment exposure condition [16], [41].

\subsection{Materials}

In this study, two different types of Brazilian Portland cements were used: one like Type III Portland cement - with high early strength [42] (Table 1), and other like Type IP Portland cement [42], with Fly Ash Type F (Table 2) - a pozzolanic cement. 
Table 1. Properties of the high early strength Portland cement, ASTM Type III.

\begin{tabular}{|c|c|c|c|c|c|c|c|c|c|c|}
\hline \multicolumn{11}{|c|}{ Chemical Properties (\%) } \\
\hline $\mathrm{SiO}_{2}$ & $\mathbf{A l}_{2} \mathbf{O}_{3}$ & $\mathrm{Fe}_{2} \mathrm{O}_{3}$ & $\mathrm{CaO}$ & MgO & $\mathrm{SO}_{3}$ & $\mathrm{Na}_{2} \mathrm{O}$ & $\mathbf{K}_{2} \mathbf{O}$ & $\mathrm{Na}_{2} \mathrm{Oeq}$ & $\begin{array}{l}\text { Loss } \\
\text { ignition }\end{array}$ & ${ }^{\text {on }}$ Insoluble Residue \\
\hline 18.86 & 4.46 & 2.75 & 61.46 & 3.93 & 3.28 & 0.23 & 0.85 & 0.79 & 3.37 & 0.76 \\
\hline \multicolumn{11}{|c|}{ Hydration heat $\left(\mathrm{J.g}^{-1}\right)$ for $41 \mathrm{h:} 328.30$} \\
\hline \multicolumn{11}{|c|}{ Mechanical and Physical Properties } \\
\hline \multicolumn{5}{|c|}{ Compressive Strength (MPa) } & \multirow{2}{*}{\multicolumn{2}{|c|}{$\begin{array}{l}\text { Specific Mass } \\
\left(\mathrm{g} / \mathrm{cm}^{3}\right)\end{array}$}} & \multirow{2}{*}{\multicolumn{3}{|c|}{ Thermal expansion (mm) }} & \multirow{2}{*}{ Blaine Fineness $\left(\mathrm{cm}^{2} / \mathrm{g}\right)$} \\
\hline 1 day & $3 \mathbf{d}$ & & 7 days & 28 days & & & & & & \\
\hline 25.6 & 38 & & 44.4 & 54.1 & & 3.09 & & 0.50 & & 4520 \\
\hline
\end{tabular}

Table 2. Properties of the Portland-pozzolan cement, ASTM Type IP.

\begin{tabular}{|c|c|c|c|c|c|c|c|c|c|c|}
\hline \multicolumn{11}{|c|}{ Chemical Properties (\%) } \\
\hline $\mathrm{SiO}_{2}$ & $\mathrm{Al}_{2} \mathrm{O}_{3}$ & $\mathrm{Fe}_{2} \mathrm{O}_{3}$ & $\mathrm{CaO}$ & MgO & $\mathrm{SO}_{3}$ & $\mathrm{Na}_{2} \mathrm{O}$ & $\mathbf{K}_{2} \mathbf{O}$ & $\mathrm{Na}_{2} \mathrm{Oeq}$ & $\begin{array}{l}\text { Loss } \\
\text { ignition }\end{array}$ & $\begin{array}{l}\text { on Insoluble } \\
\text { Residue }\end{array}$ \\
\hline 29.47 & 10.24 & 4.12 & 45.02 & 2.98 & 2.25 & 0.18 & 1.34 & 1.10 & 3.55 & 26.21 \\
\hline \multicolumn{11}{|c|}{ Hydration heat (J.g-1) for 41h: 259.00} \\
\hline \multicolumn{11}{|c|}{ Mechanical and Physical Properties } \\
\hline \multicolumn{5}{|c|}{ Compressive Strength (MPa) } & \multirow{2}{*}{\multicolumn{2}{|c|}{$\begin{array}{c}\text { Specific Mass } \\
\left(\mathrm{g} / \mathrm{cm}^{3}\right)\end{array}$}} & \multirow{2}{*}{\multicolumn{3}{|c|}{ Thermal expansion (mm) }} & \multirow{2}{*}{ Blaine Fineness $\left(\mathrm{cm}^{2} / \mathrm{g}\right)$} \\
\hline 1 day & $3 \mathrm{da}$ & & 7 days & 28 days & & & & & & \\
\hline 14.4 & 25 & & 32.8 & 46.0 & & .82 & & 1.00 & & 4180 \\
\hline
\end{tabular}

The aggregates (fine and coarse) used are potentially innocuous to ASR occurrence, as established by ASTM C1260:2018 [43] and Brazilian standard NBR 15577-1:2018 [44]. Table 3 shows the characteristics of the fine and coarse aggregates.

Table 3. Characteristics of the aggregates.

\begin{tabular}{ccc}
\hline Properties & Fine aggregate & Coarse aggregate \\
\hline Origin & Natural Pit sand & Granite - Crushing \\
\hline Maximum size & $4.75 \mathrm{~mm}$ & $19.00 \mathrm{~mm}$ \\
\hline Fineness modulus & 2.56 & 6.72 \\
\hline Specific Mass & $2.05 \mathrm{~g} / \mathrm{cm}^{3}$ & $2.68 \mathrm{~g} / \mathrm{cm}^{3}$ \\
\hline Water absorption & $3.0 \%$ & $0.40 \%$ \\
\hline Powdered material & $1.3 \%$ & $0.32 \%$ \\
\hline
\end{tabular}

Figures 2 and 3 present the particle size distribution of fine and coarse aggregates, respectively.

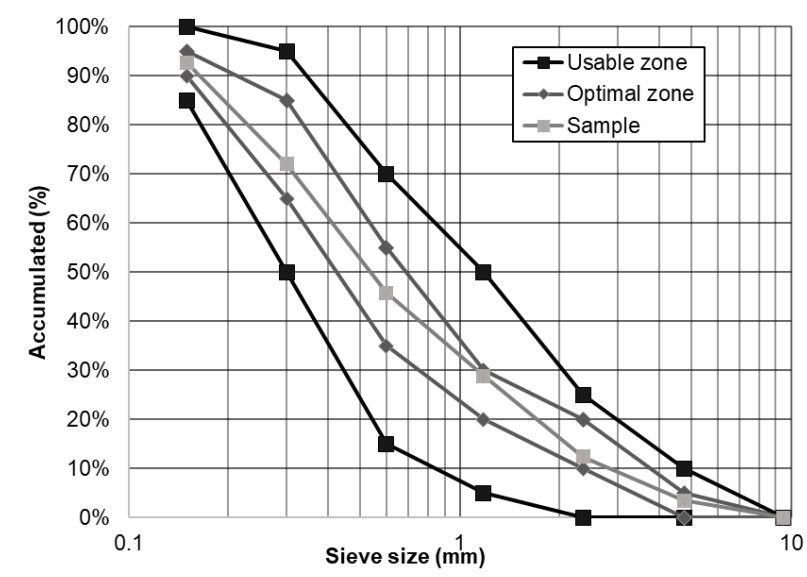

Figure 2. Particle size distribution of fine aggregate. 


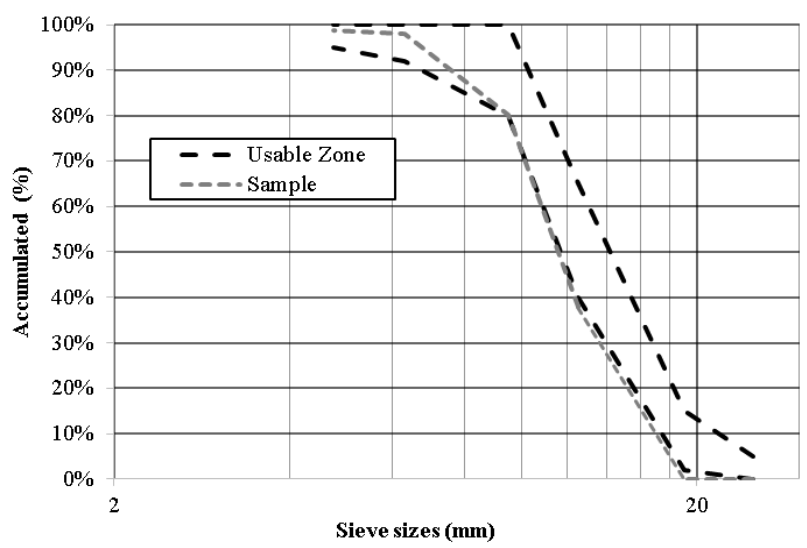

Figure 3. Particle size distribution of coarse aggregate.

\subsection{Evaluation of concrete characteristics and properties}

The physical characteristics of concretes were assessed by measuring the dimensional variation and mass variation of prismatic specimens with dimensions $(75 \times 75 \times 285) \mathrm{mm}$. Measurements of five samples were carried out weekly over 12 months. The methodology of ASTM C-1260:2018 [43] was adopted to assess the dimensional variation. The mass variation was measured on a digital scale with an accuracy of $0.001 \mathrm{~g}$.

Visual inspection of the specimens was also carried out, which consisted of verifying and photographing anomalies indicative of the occurrence of DEF.

The mechanical properties of concrete were evaluated by measuring compressive strength, splitting tensile strength, and modulus of elasticity tests at the ages of 7, 28, 56, 84, 168, 252, and 365 days, using cylindrical specimens $(100 \times 200) \mathrm{mm}$. Three specimens were cast to be evaluated by physical and mechanical tests.

The test method known as SDT (Stiffness Damage Test) was performed to obtain the SDI (Stiffness Damage Index) and PDI (Plastic Deformation Index) parameters at the same ages of mechanical properties. This test followed the procedure proposed by some researchers, such as Giannini et al. [19], Sanchez et al. [26], and Martin et al. [37], in which the specimens are subjected to five cycles of loading/unloading at a controlled loading rate of $0.10 \mathrm{MPa} / \mathrm{s}$, loading up to $40 \%$ of the 28 -day concrete strength (Figure 4 ).

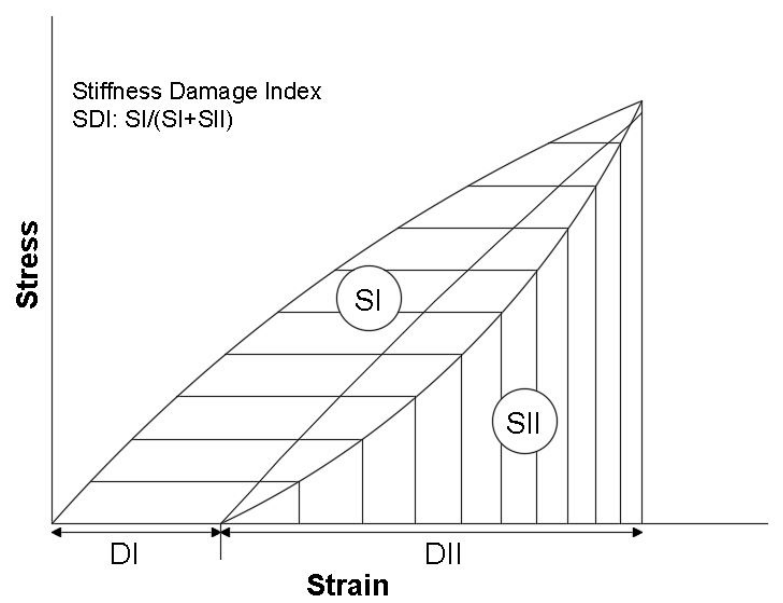

Figure 4. Stiffness Damage Test (SDT): Stiffness Damage Index (SDI) and Plastic Deformation Index (PDI) [19], [37].

The microstructure of some selected samples from concretes was assessed on fracture surfaces by a scanning electron microscope (SEM), using a secondary electron (SE) detector, and an Energy-dispersive X-ray spectroscopy (Double-EDS Detector). Samples were covered by a gold sputtering before SEM analyses. 


\section{RESULTS AND DISCUSSIONS}

\subsection{Evaluation of physical characteristics}

Indeed, according to the visual inspections some features of chemical reactions, such as whitish precipitations related to DEF (considering further confirmation by SEM/EDS) were detected prematurely, and notably for the concretes cast with Type III cement. At 56 days, those whitish spots started to appear clearer, and, over time, these symptoms began to spread over the entire surface of the evaluated concretes. After 84 days, a white material filled the voids, and, at 196 days, some mapped micro-cracks were visible (when the concrete showed expansion next to $1 \%$ ), presenting a gradual increase of white areas until the last age of evaluation (365 days), with a complete covering of the concrete surface. As for the concrete containing fly-ash, this incidence was less expressive and those symptoms became more evident later, and shortly after the age of 140 days, with some dissemination over the surface of concrete over time (Figure 5).

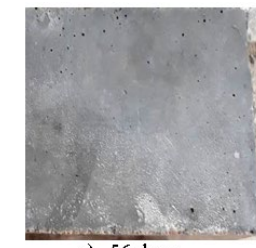

a) 56 days

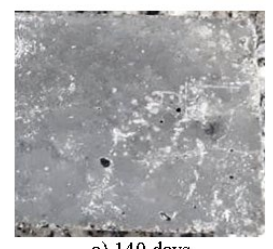

a) 140 days

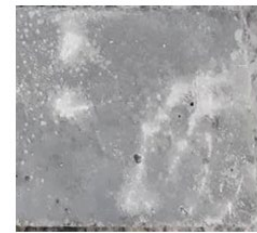

b) 112 days Type III concrete

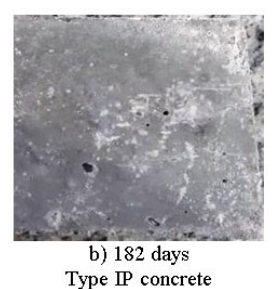

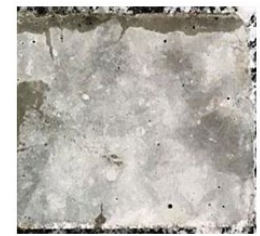

c) 203 days

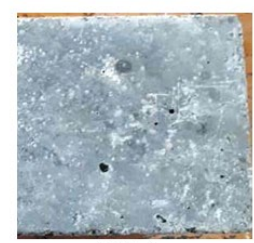

c) 252 days

Figure 5. Visual inspection of concretes.

According to [1], [5], [45]-[48], the neoformations from sulfate attack and DEF may locate in sites like voids of the cementitious matrix, paste/aggregate transition zones, and pre-existing microcracks of concrete (Figure 6). The internal expansion is influenced by parameters of concrete microstructure, which are directly dependent on the characteristics of cement and concrete. Regarding the Portland-pozzolan cement (Type IP), the signs were not so clear, since the whitish material only could be found in some punctual areas, and with more evidence just after 140 days.

Several diagnoses of DEF from Blanco et al. [49], are registered for old dams for over 30 years. The main symptoms were white precipitations in the surface cracks of concretes at both directions of the spillway, upstream and downstream. To obtain a precise diagnosis, sometimes it is necessary a specific investigation involving mechanical tests as well as microstructural analyses of concrete cores drilled from the structure, especially when there is lack of information for old structures [49]-[51].

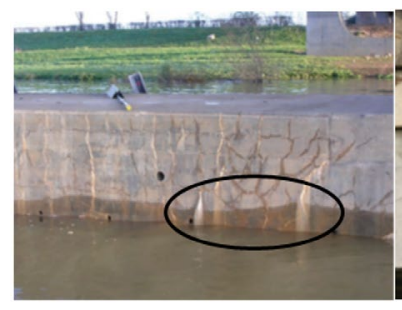

(a) Cracking of the base of a pylon (crack width $>0.3 \mathrm{~mm}$ ).

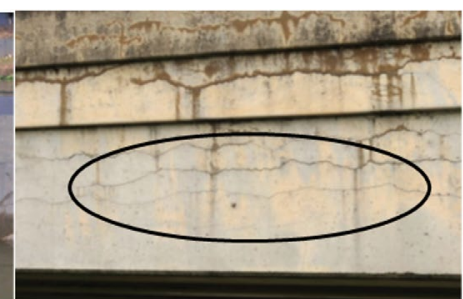

(b) Longitudinal cracks in the middle of a prestressed precast concrete beam.

Figure 6. Cracking in the surface of concrete structures due to DEF [29]. 
Figure 7 shows the expansion behavior and mass gain over time of the tested concretes. It is observed that Type III cement presented for both expansion and gain mass of concretes the highest values compared to the pozzolanic one. The maximum values obtained for expansion rates and mass gain of the samples with Type III cement were high, next to $1.2 \%$ and $2.5 \%$, respectively. For samples with Type IP cement, the values were next to $0.2 \%$ and $0.5 \%$, respectively. Some expansion results close to $1 \%$ at 168 days of testing in samples with Type III cement, reported in the literature, corroborate the results obtained in this research, thus indicating a high probability of this expansion being due to DEF [26], [48], [52]. Sanchez et al. [26] also observed higher levels of DEF expansion, such as $1.87 \%$.

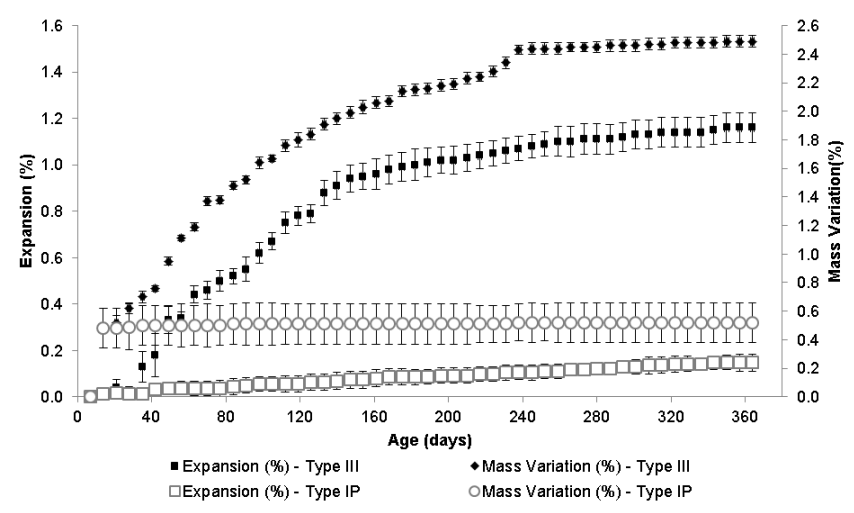

Figure 7. Expansion and mass variation of concretes over time.

The partial replacement of cement by fly ash leads to a reduction of the $\mathrm{SO}_{3} / \mathrm{Al}_{2} \mathrm{O}_{3}$ ratio. The increase in $\mathrm{Al}_{2} \mathrm{O}_{3}$ induces greater precipitation of monosulfate, leading the sulfate concentration in the pore solution to decrease. This phenomenon results in a reduction of the sulfate absorption capacity by C-S-H gels and therefore reduces the potential for DEF expansion [7], [13], [53], [54]. Delayed ettringite formation occurs due to the conversion of monosulfate and mechanisms that reduces the amount of $\mathrm{Al}_{2} \mathrm{O}_{3}$, leading to a greater amount of monosulfate and of $\mathrm{SO}_{4}{ }^{2}$ ions free or weak bound to C$\mathrm{S}-\mathrm{H}$, according to Melo [55]. This causes an increase in the neo-formed ettringite amount over time.

\subsection{Assessment of mechanical properties}

Figure 8 presents the results of the mechanical properties for both concretes. The behavior of the compressive and tensile strengths, and of the modulus of elasticity align with DEF- induced damage of concrete with Type III cement, over time. As both strengths decreased, the modulus dropped over time, and the maximum decrease occurred between three and six months. The mechanical behavior of the Portland pozzolanic concrete was different from the concrete with Type III cement. In general, a relation between compressive and tensile strengths can be observed (Figure 9). The data of tensile strength are situated between 5 and $10 \%$ of the compressive strength, presenting concrete with Type III cement a wider dispersion of values due to DEF occurrence.

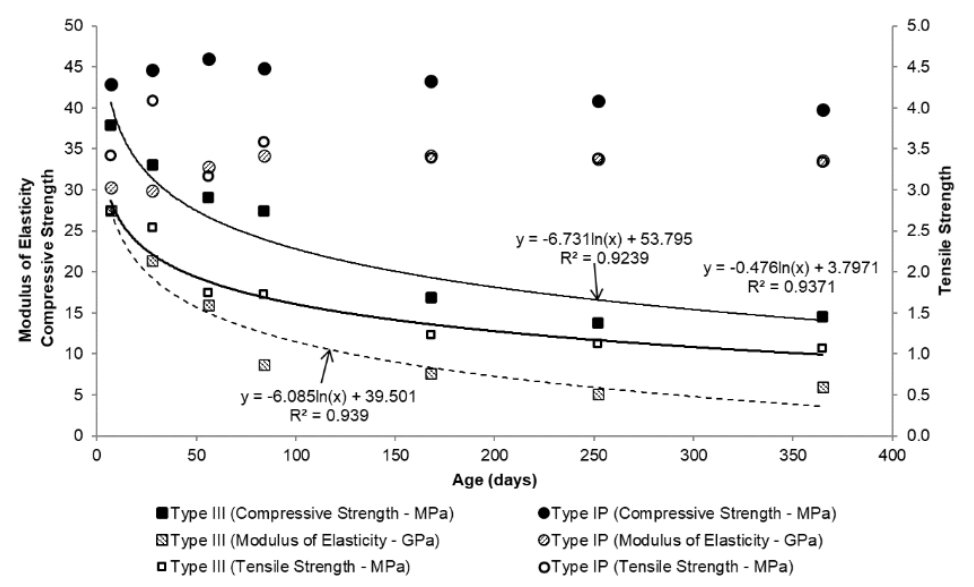

Figure 8. Evolution of mechanical properties over time. 


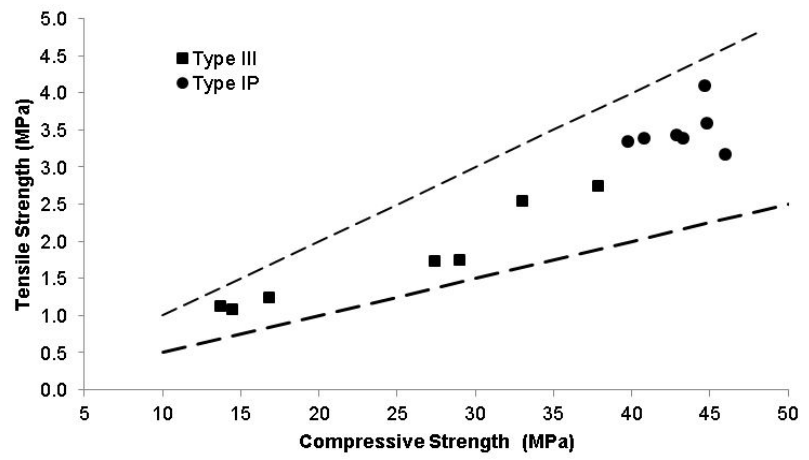

Figure 9. Relationship between tensile strength and compressive strength of concretes.

According to Figure 10, there is a good correlation between these mechanical properties. As stated by Price [54], when the value of the compressive strength is next to $18 \mathrm{MPa}$, the tensile strength represents about $10 \%$ of the compressive strength. However, for compressive strengths slightly higher, next to $25 \mathrm{MPa}$, this ratio drops to $8 \%-9 \%$. When the compressive strength presents higher values, next to $40 \mathrm{MPa}$, the tensile strength represents about $7 \%$ of the compressive strength. Due to the concrete damaged conditions, it was not possible to make predictions of the modulus of elasticity based on the compressive strength data. As previously stated by Giannini et al. [19], there is no way to predict modulus of elasticity of affected concretes based on standard codes.

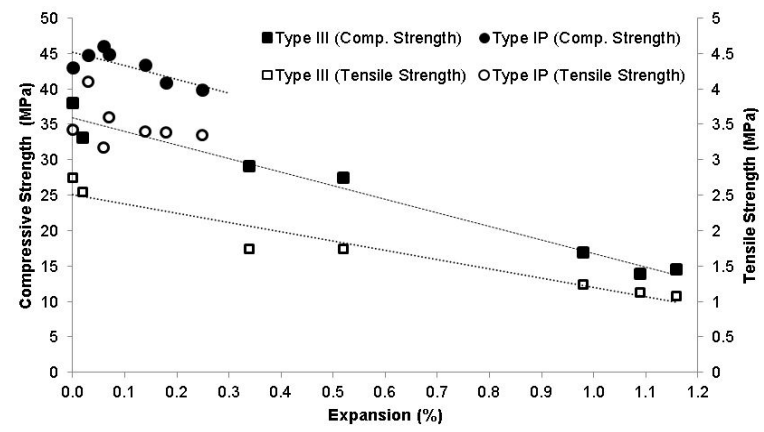

Figure 10. Relationship between the tensile and compressive strengths versus expansion.

Figure 11 shows the correlation of the results obtained experimentally to those obtained from the equations of Brazilian standard code ABNT NBR 6118: 2014 [56] $\left(\mathrm{E}_{\mathrm{ci}}=5600 \sqrt{\mathrm{fck}}\right)$ and ACI 318: 2014 [57] $\left(\mathrm{E}_{\mathrm{ci}}=4730 \sqrt{\mathrm{fc}}\right)$. It is possible to observe that DEF expansions caused negative effects on the mechanical properties (Figures 12, 13 and 14).

Even for the Portland pozzolanic concrete, both strengths decreased, although with less damage (bellow $10 \%$ for the maximum expansions detected) compared to concrete with Type III cement (next to $60 \%$ at higher expansion level above $1 \%$ ).

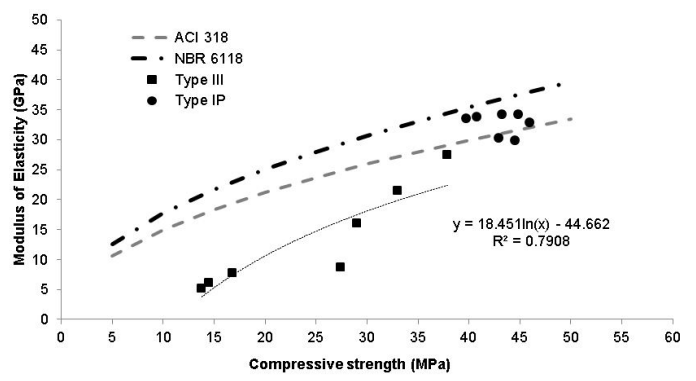

Figure 11. Correlation between the experimentally results of modulus of elasticity and compressive strength with the estimated results from Brazilian standard code ABNT NBR 6118:2014 [56] and ACI 318:2014 [57]. 


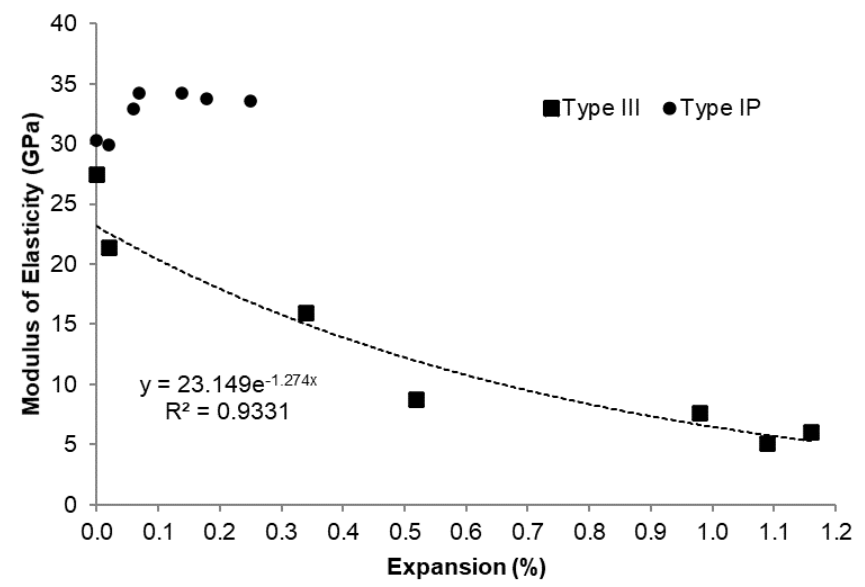

Figure 12. Relationship between modulus of elasticity versus expansion.

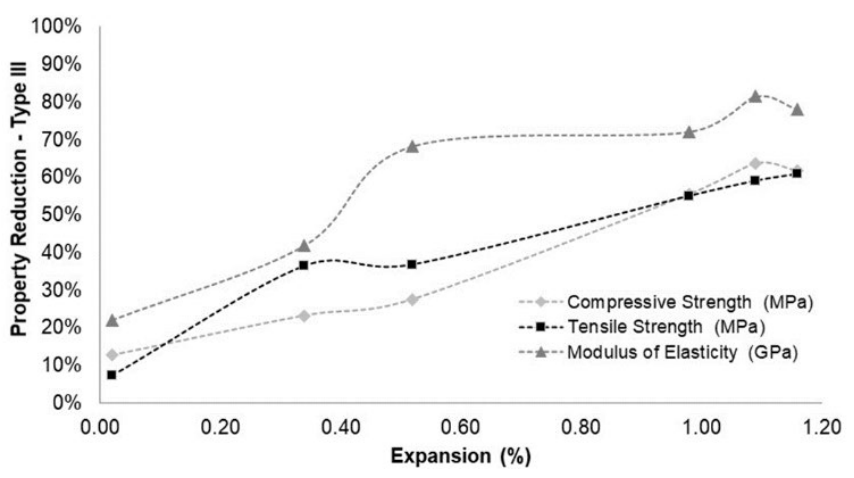

Figure 13. Correlation between the mechanical properties and expansion for Type III cement.

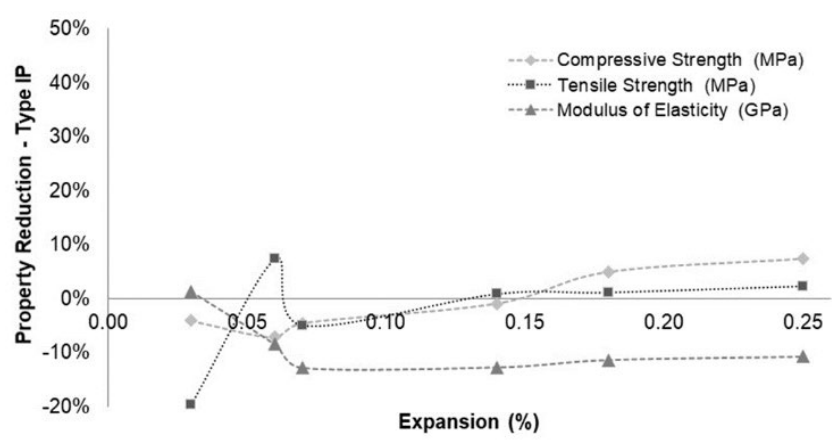

Figure 14. Correlation between the mechanical properties and expansion for Type IP cement.

For expansion levels of $0.20 \%-0.40 \%$, the decrease of tensile strength was next to $40 \%$. According to the literature [26], [54], some DEF-affected concrete structures showed a reduction of tensile strength next to $65 \%$. The modulus of elasticity presented a drop of about $80 \%$ with the high DEF induced expansion (over $1 \%$ ) for concrete with Type III cement (Figure 13) whereas expansions up to $0.25 \%$ did not impact this property in the presence of pozzolanic cement (Figure 14). According to [19], [58], deleterious effects on the modulus of elasticity can arise even before the occurrence of significant expansions. 
In the literature, some researchers agree that DEF expansions negatively affect the mechanical properties of concrete [19], [24], [58]. However, some studies pointed to negative results of compressive strength (drop of $50 \%$ ) when the expansion values are remarkably high, next to $1.50 \%$ [1], [3], [23].

\subsection{Stiffness Damage Test (SDT)}

Figures 15 and 16 show the stress-strain curves plot with SDT results for concretes with Type III cement and Type IP cement, respectively, considering the six evaluated ages. For concrete with Type III cement, a gradual increase in deformation is observed over time, as the expansions increase. This behavior is intrinsically related to the microcracking caused by DEF stresses, thus weakening the concrete. At 365 days, expansions above $1 \%$ caused very high deformations. The SDI at 365 days represents next to four times the deformation obtained at 28 days. So, with larger hysteresis areas in the stress-strain plots, there is dissipated energy and more plastic deformation accumulated, resulting in loss of stiffness. Similar behavior was observed by Giannini et al. [19], Sanchez et al. [26], Martin et al. [37] and Smaoui et al. [59].

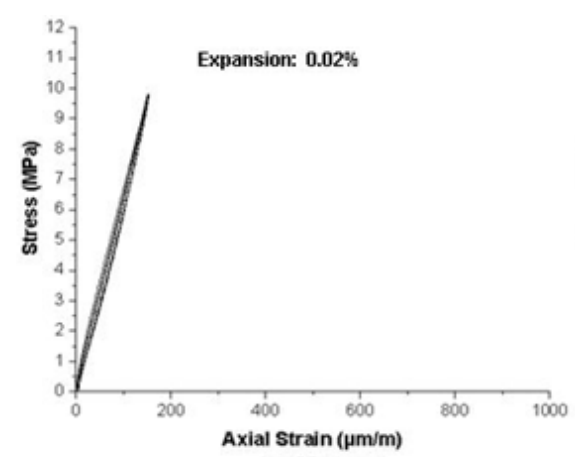

(a) 28 days.

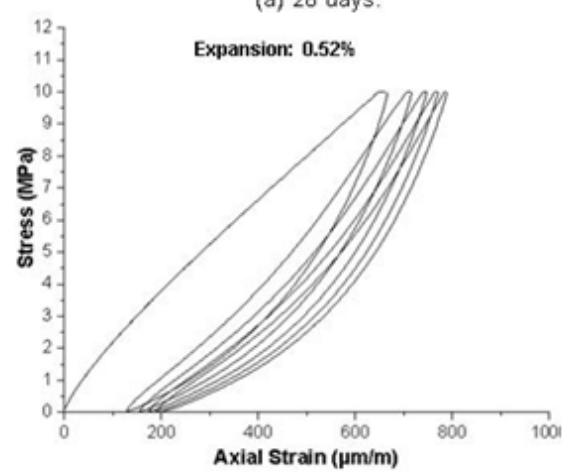

(c) 84 days.

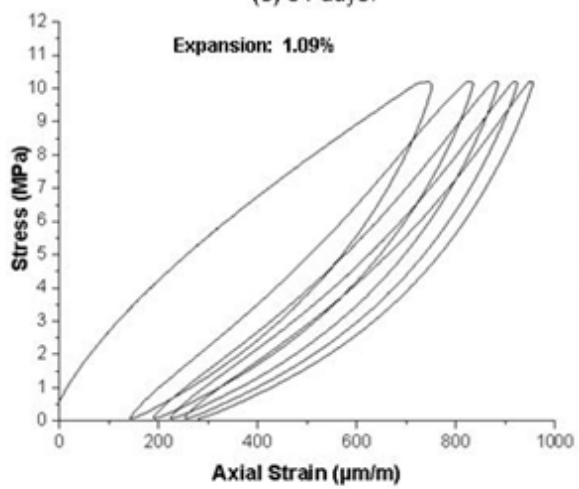

(e) 252 days

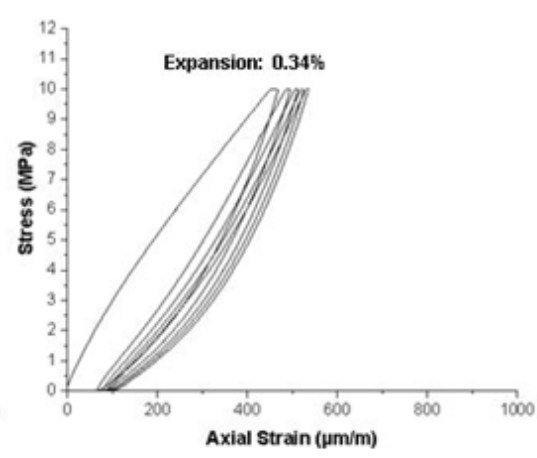

(b) 56 days.

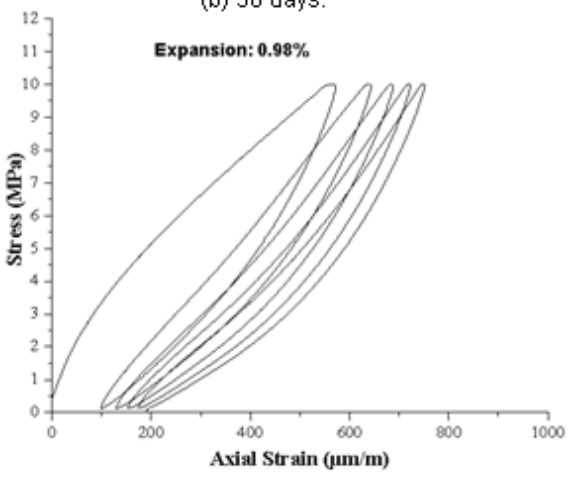

(d) 168 days.

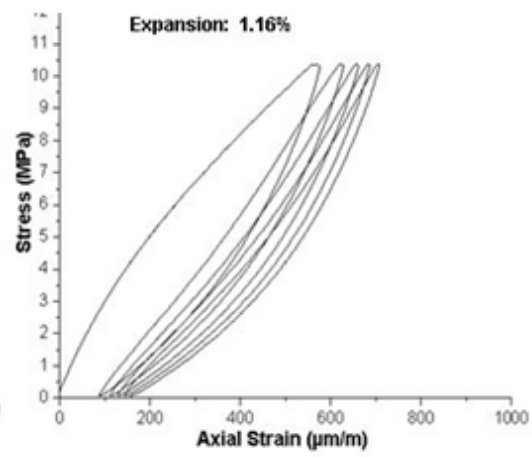

(f) 365 days.

Figure 15. Results of Stiffness Damage Test (SDT) for Type III cement. 


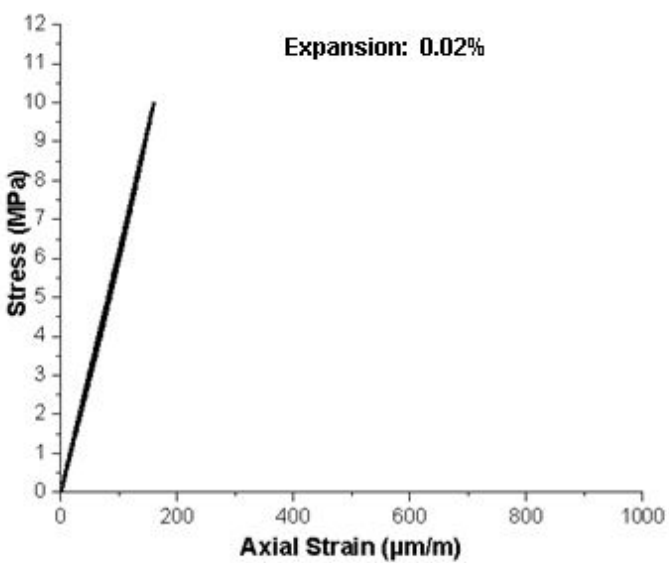

(a) 28 days.

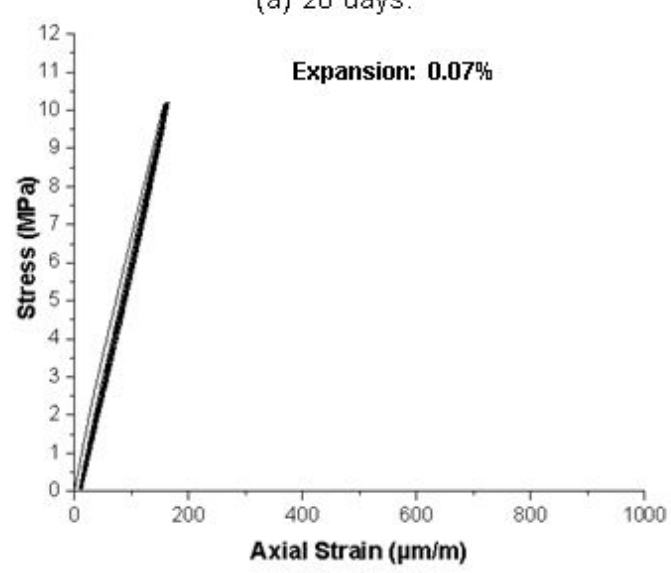

(c) 84 days.

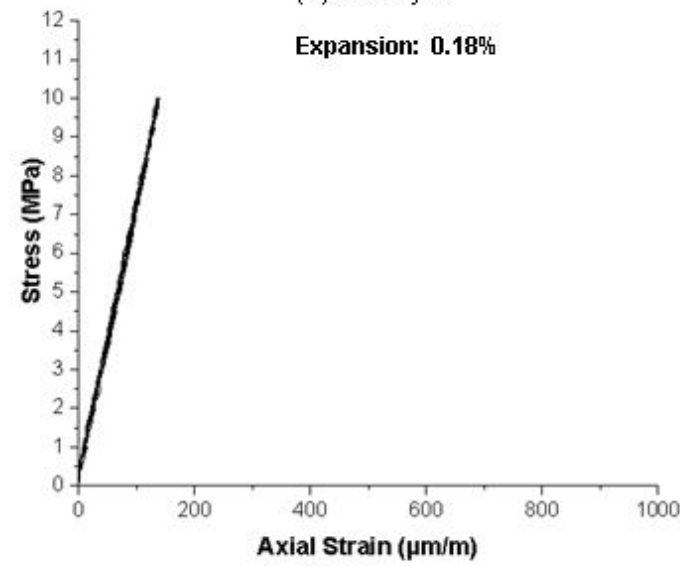

(e) 252 days.

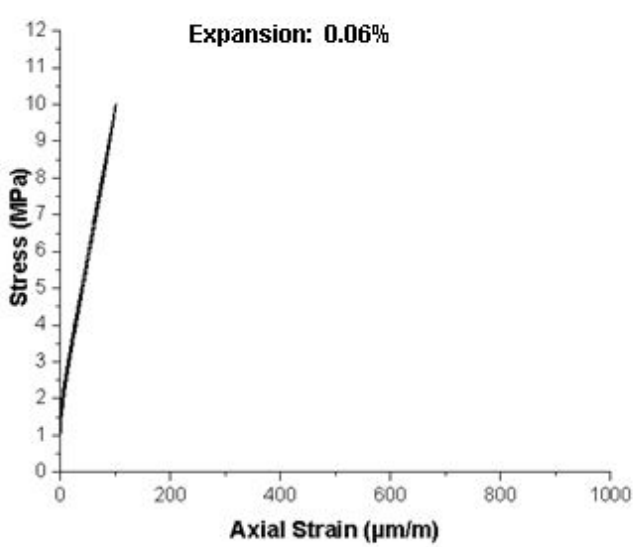

(b) 56 days.

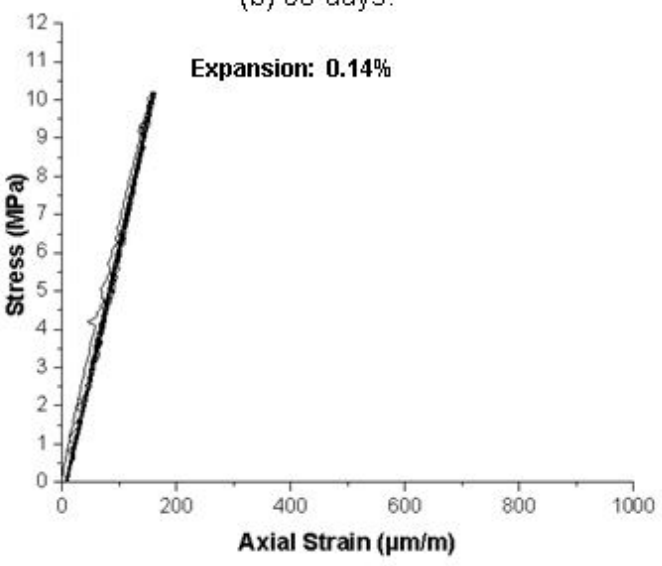

(d) 168 days.

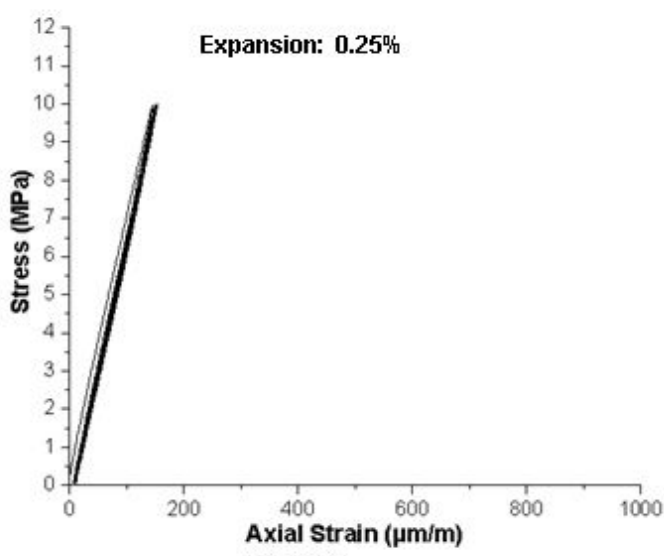

(f) 365 days.

Figure 16. Results of Stiffness Damage Test (SDT) for Type IP cement.

Figures 17 and 18 show that after the second month of testing, when the expansions were already expressive and the values of the mechanical properties decreased, the SDT was not sensitive enough to detect the DEF progress over time, showing little variation until 365 days. Concretes with Type IP cement showed different behavior, the Stiffness Damage Index (SDI) and Plastic Deformation Index (PDI) were lower than for concretes with Type III cement. Besides, the maximum expansion achieved was next to $0.2 \%$, indicating there were no important changes over time by using SDT. 


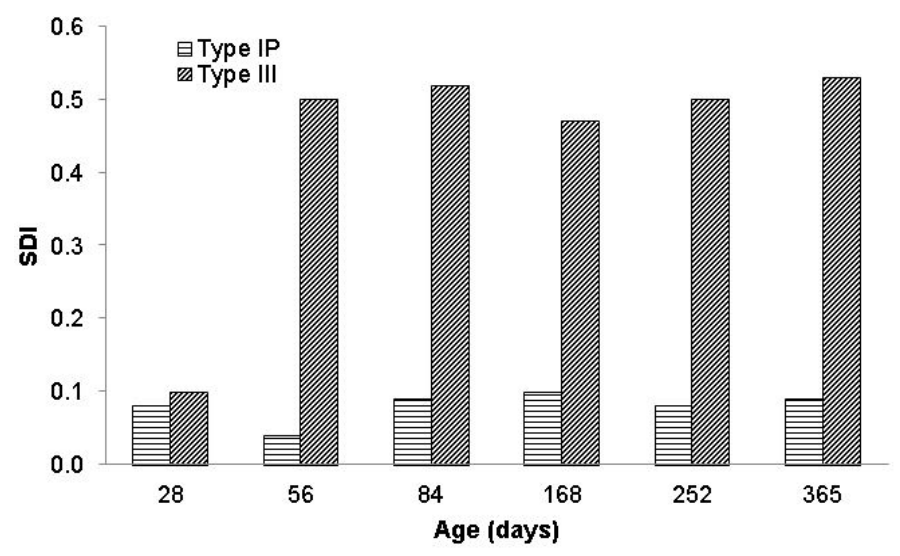

Figure 17. Stiffness Damage Index (SDI) of concretes over time.

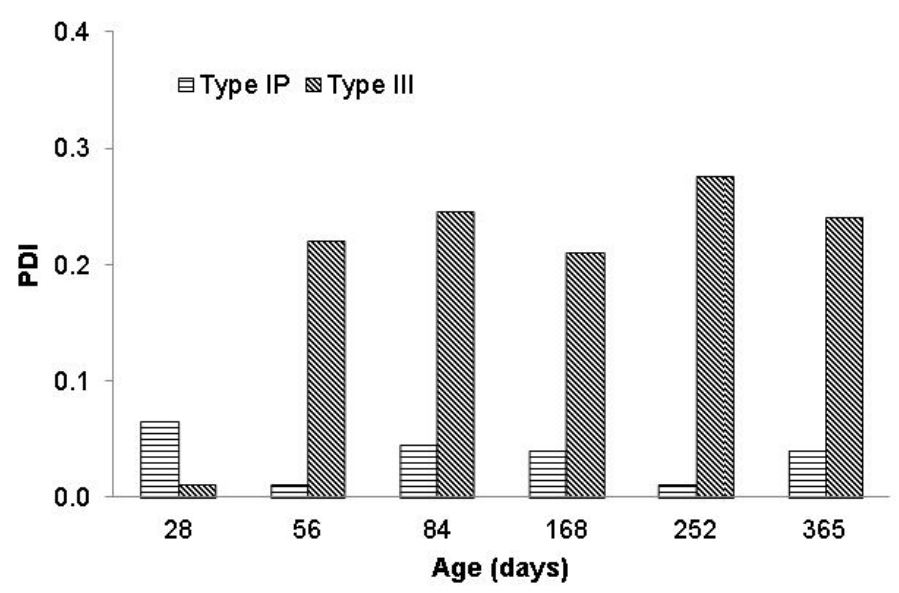

Figure 18. Plastic Deformation Index (PDI) of concretes over time.

Figure 19 presents a correlation between the modulus of elasticity and the Stiffness Damage Index (SDI). For concrete with Type III cement, when the modulus of elasticity decreases, the SDI increases. The same does not occur for concrete with pozzolanic cement.

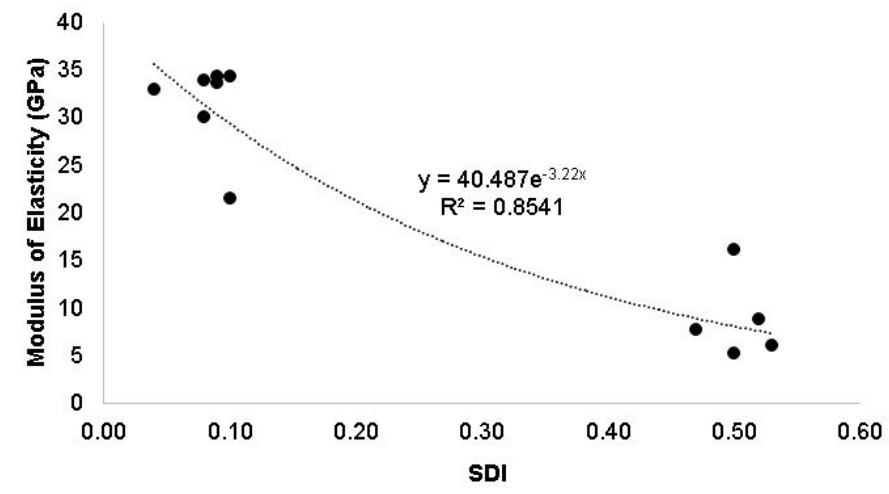

Figure 19. Correlation between Stiffness Damage Index (SDI) and modulus of elasticity.

Figure 20 shows the correlation between expansion, Stiffness Damage Index (SDI), and Plastic Deformation Index (PDI). Concrete with Type III cement presented SDI values in the range of 0.10 to 0.53 , while the expansion values were 
in the range of $0.02 \%$ to $1.16 \%$. For concrete with Type IP cement, the SDI values varied from 0.04 to 0.10 and the expansions from $0.02 \%$ to $0.25 \%$. However, for concrete with Type III cement, the SDI did not show important variations for expansions above of $0.34 \%$, being in the range of 0.47 to 0.53 . The SDI value for concrete with pozzolanic cement did not increase when compared to the higher expansion values, since the level of expansions does not exceed $0.25 \%$.

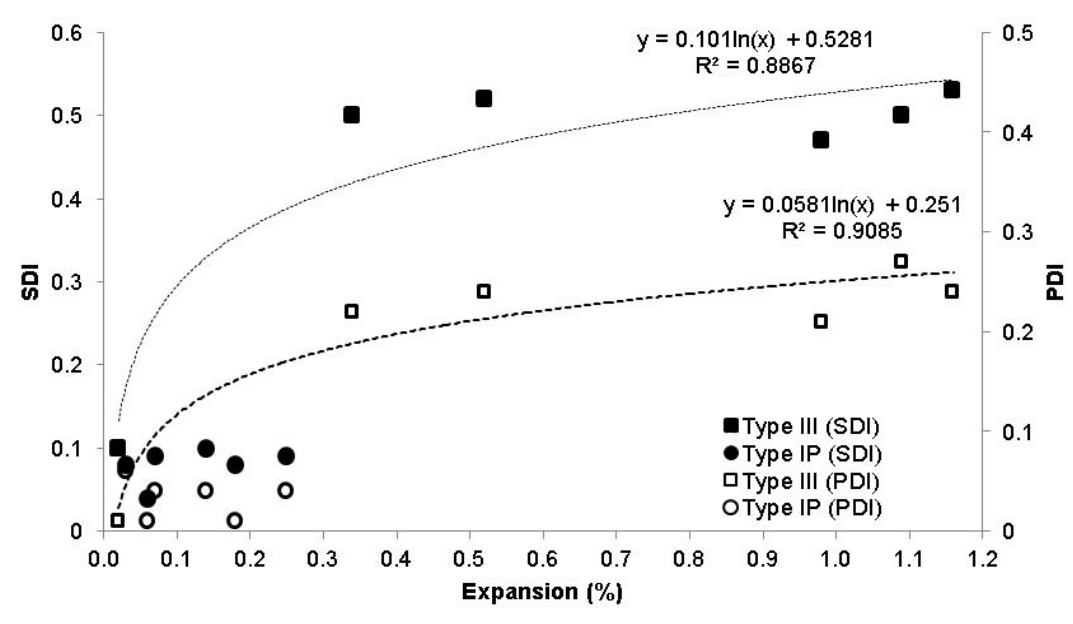

Figure 20. Correlation between expansion, Stiffness Damage Index (SDI), and Plastic Deformation Index (PDI).

In general, the behaviors of SDI and PDI were similar for the concretes with both types of cement. However, the Stiffness Damage Index (SDI) seems to have adhered better to the DEF behavior in the present study. Concerning the Plastic Deformation Index (PDI), this parameter can assist in damage identification of concrete, especially when studying pathological phenomena related to permanent dimensional change, that is, when exceeding the limits of elastic deformation [19]. In this sense, it is observed that the concrete with Type III cement presented permanent deformations due to the high level of triggered expansibility.

Concerning the results obtained in the present study for concrete with Type III cement, higher values were observed for SDI compared to PDI for similar expansion rates (of the order of 1.0\%), when compared to the few data available and published in the international literature. In this study, the values obtained for SDI and PDI were 0.53 and 0.27 , respectively, while for Giannini et al. [19], these values were in the order of 0.57 and 0.49, and, for Sanchez et al. [26], 0.38 and 0.33, respectively. In other words, for DEF affected concretes, in the range of $1 \%$ expansion, the concrete with Type III cement showed more stiffness damage.

\subsection{Evaluation of microstructural characteristics}

Figures 21 and 22 show the microstructural characteristics of the samples analyzed over time and up to 365 days by SEM/EDS. The first ettringite crystals neoformations were visualized at 28 days for concrete with Type III cement (Figure 21), filling the voids of the concrete. After 168 days, there were massive agglomerations of these neoformations. At this age, a weakened cement-aggregate transition zone and many ettringite crystals around the aggregates were observed. After 365 days, concrete was completely fragile, with relevant neoformations, indicating extreme deterioration. The analysis of the microstructure of concrete with Type III cement was consistent with the mechanical properties drop over time. It was also consistent with the high expansion levels, over $1 \%$. On the other hand, the pozzolanic concrete (Figure 22) showed scarce voids with ettringite at 28 days. The deposition of ettringite crystals increased over time, but less intensely than for concrete with Type III cement. At 168 days, some massive formations in the cement matrix and voids filled with ettringite gave rise as it was detected by SEM, although there were still some preserved transition zones. At 365 days, the pozzolanic concrete had already obtained microstructural features linked to DEF development, although less intensely than for concrete with Type III cement. Even so, the microstructural and mechanical evaluations were also consistent for the pozzolanic concrete up to the evaluated age. 


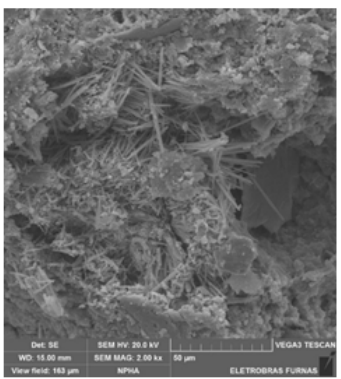

(a) 28 days

Well-visible acicular crystals in the cement paste

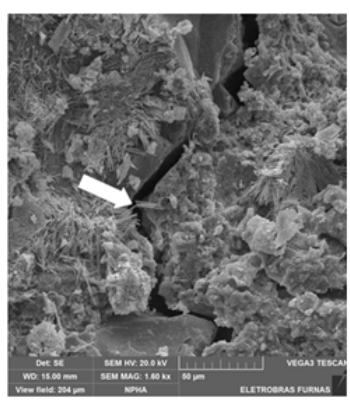

(d) 168 days.

Interfacial Transition Zone (ITZ) weakened due to DEFattacked, plenty of neoformations on the surrounding zone.

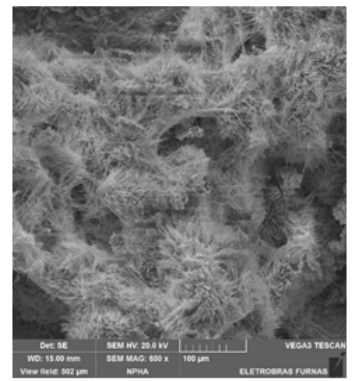

(b) 56 days

Agglomerations of secondary ettringite filling most void.

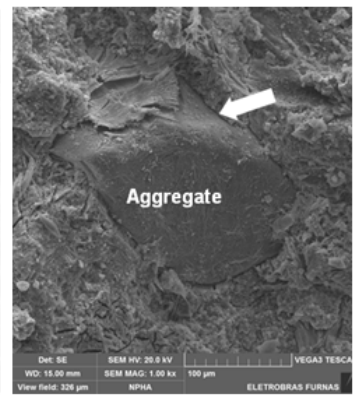

(e) 252 days. Plenty of ettringite neoformations on the aggregate and surrounding zone.

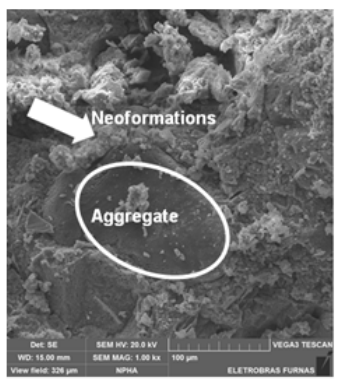

(c) 84 days

Plenty of powder material in the cement matrix and neoformations of around the aggregate.

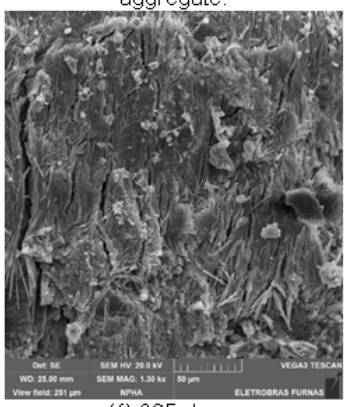

(f) 365 days

Cement matrix completely fragile due to the compacted ettringite

Figure 21. Micrographs of concrete with Type III cement.

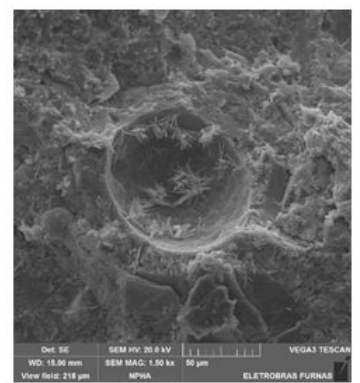

(a) 28 days

Few pores with ettringite acicular crystals.

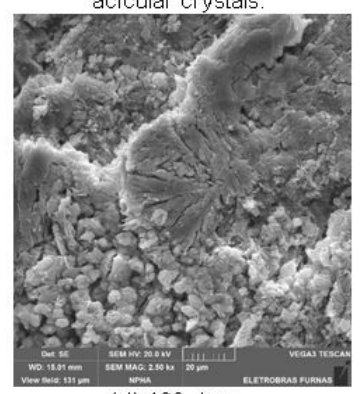

(d) 168 days.

Massive formations of ettringite compacted in the cement matrix.

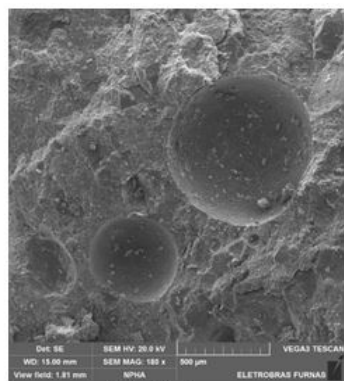

(b) 56 days

Voids with rare formations.

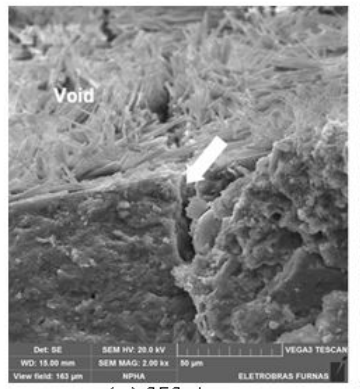

(e) 252 days.

A radial micro-crack was observed on the edge of a pore fulfilled with secondary ettringite formations.

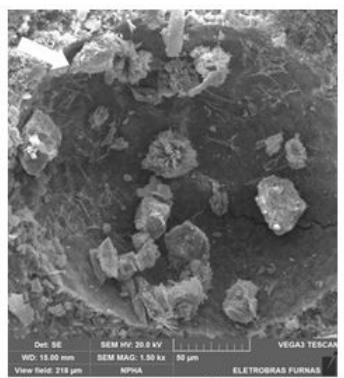

(c) 84 days.

Some ettringite pellets in a void.

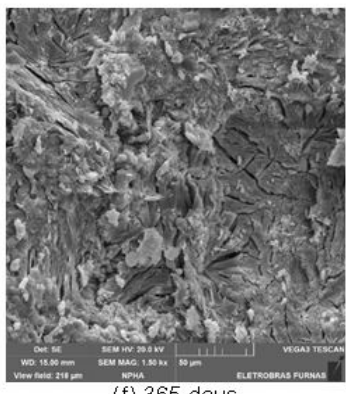

(f) 365 days

Extensive growth of compacted ettringite in the cement matrix. indicating DEF.

Figure 22. Micrographs of concrete with Type IP cement. 
The microstructural analyses performed by Bragança et al. [60], show some similarities in the microstructure of concrete affected from DEF, especially the presence of massive ettringite and microcracks, but the extent of expansions detected at one year was lower, and below $0.05 \%$, and the tests were performed with mortars. In the present study, concrete specimens were evaluated and besides the characteristics mentioned before, it was possible to detect higher expansions $(1.2 \%$ for Type III cement and $0.25 \%$ for Type IP cement) at one year, and the microstructural characteristics indicate a high level of concrete deterioration due to the intense massive formations as well as fragilities in the ITZ, for type III cement.

\subsection{General Overview and Discussions}

In order to perform a global analysis of the DEF damage considering the progress of expansive reactions and all data obtained from the mechanical behaviors of concretes without pozzolan, Table 4 summarizes data based upon the level of expansions, as previously performed by Sanchez et al. [26] for DEF and other expansive mechanisms.

Table 4. Global analyses of DEF damage for concretes without admixture.

\begin{tabular}{|c|c|c|c|c|c|c|}
\hline \multirow[b]{2}{*}{ Level of damage } & \multirow{2}{*}{$\begin{array}{c}\text { Level of } \\
\text { expansion }(\%)\end{array}$} & \multicolumn{3}{|c|}{ Maximum reduction (\%) observed on the } & \multicolumn{2}{|c|}{ Data for } \\
\hline & & $\begin{array}{c}\text { Compressive } \\
\text { strength }\end{array}$ & Tensile strength & $\begin{array}{c}\text { Modulus of } \\
\text { elasticity }\end{array}$ & SDI & PDI \\
\hline Moderate & $0.02-0.03$ & 13 & 7 & 22 & 0.10 & 0.01 \\
\hline High & $0.04-0.20$ & 25 & 23 & 45 & - & - \\
\hline Very High & $0.30-0.52$ & 28 & 37 & 68 & 0.52 & 0.24 \\
\hline Ultra high & $0.53-1.10$ & 64 & 59 & 82 & 0.50 & 0.27 \\
\hline & $\geq 1.10$ & 62 & 61 & 78 & 0.53 & 0.24 \\
\hline
\end{tabular}

According to data from Table 4, modulus of elasticity is the more affected property by the increasing expansions, and over time compared to both strengths, as expected. Considering the level "moderate damage" and expansion below $0.03 \%$, the loss for modulus can achieve $22 \%$, but the stiffness damage index indicates 0.10 . Sanchez et al. [26] observed a similar SDI-value for DEF mechanism. In the "high level of damage", loss on the compressive strength duplicates as well as for modulus of elasticity (loss of 25 and $45 \%$, respectively) and triplicates for the tensile strength ( $23 \%$ of loss), signing a high damage from $0.04 \%$ of DEF expansions. For higher levels of expansion (above $0.30 \%$ ), damage is extremely high, and seriously reflecting in all mechanical properties as shown by a high level of both stiffness damage index as well as plastic deformation index. SDI in this study achieved 0.52 , higher than those verified by Sanchez et al. Around $1 \%$ of expansions, about $80 \%$ of modulus can be reduced damaging severely the concrete, with losses of the order of $60 \%$ for both strengths; Sanchez et al. [26] verified similar mechanical behaviors for the expansive mechanisms studied. In this study the microstructural analyses by SEM were included to corroborate damages caused by the type of ettringite crystals formed as well as the places they were accommodated. Thus, it was possible to explain those high level of deteriorations. For example, after 56 days several ettringite crystals had already been produced in the cement matrix filling several voids, indicating a premature DEF process. Over time it was perceived a progress of those neoformations, with the presence of massive ettringite and microcracking at 6 months, with injuries to the interfacial transition zone (ITZ), justifying the losses for the mechanical properties, but specially for the modulus of elasticity, with expressive expansions of about $1 \%$. From this point, there was a small increase in the expansions since the level of damage had been extremely high leading to a fragile cement matrix besides affecting completely the integrity of the concrete. In the studies from Bragança et al. [60], from levels of expansion of $0.015 \%$, the elastic modulus tends to reduce as the expansions increases. The modulus was negatively influenced at about $35 \%$ of loss at one year.

In the case of pozzolanic cement, with fly ash, the behavior was different considering a global analyses of DEF damage since neither modulus of elasticity nor SDT indexes were affected by expansions up to $0.25 \%$; SDI remained at 0.10 and PDI achieved 0.04 for this high level of expansion. On the other hand, in relation to the strengths, above $0.14 \%$ of expansion caused a decrease of about $18 \%$ for tensile strength, and considering expansions of $0.18 \%$, a decrease of about $10 \%$ was detected for compressive strength, considering the reference age of 28 days. This behavior can suggest the long term of fly ash in acting as pozzolanic material and a self-healing effect over time. Nevertheless, it is important to perform internal microstructural analyses by SEM to check if pozzolan inhibited the expansive process from DEF or just promoted a delay on the expansion behavior and the damages. From this view, an alert must be registered since the internal integrity of this concrete was effectively impaired by DEF. Thus, the expansive process 
and damage was just delayed for this type of cement based upon the SEM analyses (Figure 22). Differently from the concrete without pozzolan, the first important microstructural signs were verified around six months, considering the massive formations dispersed along the cement matrix. At this point, expansions achieved $0.14 \%$, justifying negative impacts in the tensile strength. Considering nine months, some cracks were identified in the cement paste, leading to losses in the compressive strength (with $0.18 \%$ of expansion), but no reduction neither in the modulus of elasticity nor in the SDT indices, yet. Injuries in the ITZ were not detected up to one year for this concrete. The fact is that the ettringite observed by SEM at 365 days seems that will take more time to induce modulus reductions by cracks in the ITZ. Thus, further ages are necessary to be monitored by SEM. The process for this type of concrete differs from the one without admixture. Some studies related to the use of SCMs and pozzolans indicate this behavior, such the one published by Silva et al. [61] and other research [12], [52], [55].

\section{CONCLUSIONS}

Delayed ettringite formation (DEF) was evaluated through physical, mechanical, and microstructural analyses and correlated to expansions of two concretes, with and without fly-ash, over time. The main purpose of this research was to perform a global analysis of DEF based on multiple analyses and the major conclusion is that both concretes with (Type IP cement) and without fly-ash (Type III cement) suffered from DEF, even though in different levels of deterioration. The mechanical properties were affected prematurely for concrete with Type III cement, achieving high levels of damage with expressive expansions, of about $1 \%$ at one year. As to concrete tested with Type IP cement it was noted just a time delay on the expansive and deterioration process caused by DEF, due to the presence of fly-ash. Notwithstanding, elasticity modulus and SDT indexes were not yet affected up to one year, the high level of expansions detected $(0.25 \%)$ has already led this concrete to damages reflected in the strength at one year and important proofs of the presence of massive ettringite and microcracking associated to DEF by microstructural analysis indicating internal deterioration and the potential progress of DEF over time.

In brief, the performance and durability of concrete structures in the field depends on several factors, including the type of cement, and premature tests for DEF in the laboratory, even in concrete, can promote false-negative results and risks of high levels of damage due to the expansive behavior of this phenomenon. The expansive suppression mechanisms by fly-ash are complex and still limited for DEF phenomenon. A specific topic related to expansive mechanisms, such as DEF, must be included in the design phase and an appropriate technological control during the production, curing and placing of concretes are mandatory.

\section{ACKNOWLEDGEMENTS}

This work had financial and infrastructure support from Furnas Centrais Elétricas S.A./ANEEL, P\&D 0394-1504-2015. D. Schovanz benefits from a partial scholarship financed by the Research Foundation of the State of Rio Grande do Sul FAPERGS by the FAPERGS Grant.

\section{REFERENCES}

[1] H. F. W. Taylor, C. Famy, and K. L. Scrivener, "Delayed ettringite formation," Cement Concr. Res., vol. 31, no. 5, pp. 683-693, 2001, http://dx.doi.org/10.1016/S0008-8846(01)00466-5.

[2] M. Collepardi, "A state-of-the-art review on delayed ettringite attack on concrete," Cement Concr. Compos., vol. 25, no. 4-5, pp. 401-407, 2003, http://dx.doi.org/10.1016/S0958-9465(02)00080-X.

[3] Y. Gu, R.-P. Martin, O. Omikrine Metalssi, T. Fen-Chong, and P. Dangla, "Pore size analyses of cement paste exposed to external sulfate attack and delayed ettringite formation," Cement Concr. Res., vol. 123, pp. 105766, 2019, http://dx.doi.org/10.1016/j.cemconres.2019.05.011.

[4] A. Pichelin, M. Carcassès, F. Cassagnabère, S. Multon, and G. Nahas, "Sustainability, transfer and containment properties of concrete subject to delayed ettringite formation (DEF)," Cement Concr. Compos., vol. 113, pp. 103738, 2020, http://dx.doi.org/10.1016/j.cemconcomp.2020.103738.

[5] P. K. Mehta and P. J. M. Monteiro, Concreto: Estrutura, Propriedades e Materiais. 2. ed. São Paulo: IBRACON, 2014.

[6] L. F. M. Sanchez, T. Drimalas, B. Fournier, D. Mitchell, and J. Bastien, "Comprehensive damage assessment in concrete affected by different internal swelling reaction (ISR) mechanisms," Cement Concr. Res., vol. 107, pp. 284-303, 2018, http://dx.doi.org/10.1016/j.cemconres.2018.02.017.

[7] L. F. M. Sanchez, T. Drimalas, and B. Fournier, "Assessing condition of concrete affected by internal swelling reactions (ISR) through the Damage Rating Index (DRI)," Cement, vol. 1-2, 100001, 2020, http://dx.doi.org/10.1016/j.cement.2020.100001. 
[8] W. Deboucha, N. Leklou, A. Khelidj, and O. Plé, "Combination effect of limestone filler and slag on delayed ettringite formation in heat-cured mortar," J. Mater. Civ. Eng., vol. 32, 04019365, 2020.

[9] C. S. Poon, L. Lam, and Y. L. Wong, "A study on high strength concrete prepared with large volumes of low calcium fly ash," Cement Concr. Res., vol. 30, pp. 447-455, 2000.

[10] W. H. R. S. Dayarathne, G. S. Galappaththi, K. E. S. Perera, and S. M. A. Nanaykkra, "Evaluation of the potential for delayed ettringite formation in concrete," in Proc. 19th ERU Symp., Moratuwa, Sri Lanka, 2013.

[11] V. H. Nguyen, N. Leklou, J.-E. Aubert, and P. Mounanga, "The effect of natural pozzolan on delayed ettringite formation of the heatcured mortars," Constr. Build. Mater., vol. 48, pp. 479-484, 2013., http://dx.doi.org/10.1016/j.conbuildmat.2013.07.016.

[12] Y. Amine, N. Leklou, and O. Amiri, "Effect of supplementary cementitious materials (SCM) on delayed ettringite formation in heatcured concretes," Energy Procedia, vol. 139, pp. 565-570, 2017, http://dx.doi.org/10.1016/j.egypro.2017.11.254.

[13] N. Leklou, V. Nguyen, and P. Mounanga, "The effect of the partial cement substitution with fly ash on Delayed Ettringite Formation in heat-cured mortars," KSCE J. Civ. Eng., vol. 21, no. 4, pp. 1359-1366, 2017., http://dx.doi.org/10.1007/s12205-016-0778-9.

[14] Y. Zhang, Y. Pan, and D. Zhang, "A literature review on delayed ettringite formation: mechanism, affect factors and suppressing methods," Mag. Concr. Res., vol. 73, no. 7, pp. 325-342, 2021.

[15] J. L. Bronholo, "Estudo do ataque individual e misto de DEF e RAA e de seus efeitos deletérios nas propriedades físico-químicas e mecânicas de concretos e argamassas de cimento Portland pozolânico e de alta resistência," M.S. thesis, Inst. Tecnol. Desenvolv LACTEC, 2020.

[16] D. Schovanz, "Study on delayed ettringite formation (DEF) in concretes with Portland-pozzolan cement and high early strength Portland cement," M.S. thesis, Fac. Meridional, Passo Fundo, 2019.

[17] Y. K. Ramu, V. Sirivivatnanon, P. Thomas, Y. Dhandapani, and K. Vessalas, "Evaluating the impact of curing temperature in delayed ettringite formation using electrochemical impedance spectroscopy," Constr. Build. Mater., vol. 282, pp. 122726, 2021, http://dx.doi.org/10.1016/j.conbuildmat.2021.122726.

[18] M. Jebli, F. Jamin, C. Pelissou, E. Lhopital, and M. S. E. Youssoufi, "Characterization of the expansion due to the delayed ettringite formation at the cement paste-aggregate interface," Constr. Build. Mater., vol. 289, pp. 122979, 2021, http://dx.doi.org/10.1016/j.conbuildmat.2021.122979.

[19] E. R. Giannini, L. F. M. Sanchez, A. Tuinukuafe, and K. J. Folliard, "Characterization of concrete affected by delayed ettringite formation using the stiffness damage test," Constr. Build. Mater., vol. 162, pp. 253-264, 2018, http://dx.doi.org/10.1016/j.conbuildmat.2017.12.012.

[20] T. Ahmed, E. Burley, S. Rigden, and A. I. Abu-Tair, "The effect of alkali reactivity on the mechanical properties of concrete," Constr. Build. Mater., vol. 17, no. 2, pp. 123-144, 2003.

[21] A. Pavoine, X. Brunetaud, and L. Divet, "The impact of cement parameters on Delayed Ettringite Formation," Cement Concr. Compos., vol. 34, no. 4, pp. 521-528, 2012, http://dx.doi.org/10.1016/j.cemconcomp.2011.11.012.

[22] X. Brunetaud, L. Divet, and D. Damidot, "Impact of unrestrained Delayed Ettringite Formation-induced expansion on concrete mechanical properties," Cement Concr. Res., vol. 38, no. 11, pp. 1343-1348, 2008, http://dx.doi.org/10.1016/j.cemconres.2008.05.005.

[23] L. F. M. Sanchez, B. Fournier, M. Jolin, M. J. Bastien, and D. Mitchell, "Practical use of the Stiffness Damage Test (SDT) for assessing damage in concrete infrastructure affected by alkali-silica reaction," Constr. Build. Mater., vol. 125, pp. 1178-1188, 2016, http://dx.doi.org/10.1016/j.conbuildmat.2016.08.101.

[24] J. Jeong, H. Ramézani, and N. Leklou, "Porous-micro-dilatation theory for random crystallization: Monte Carlo simulation for delayed ettringite formation," Acta Mech., vol. 228, no. 9, pp. 3223-3249, 2017., http://dx.doi.org/10.1007/s00707-017-1863-y.

[25] J. F. Seignol, O. Omikrine-Metalssi, N. Baghdadi, and F. Toutlemonde, "From AAR to DEF: numerical modeling of structures affected by expansive reactions in concrete," in Proc. 14th Int. Conf. on AAR Concr., 2012.

[26] L. F. M. Sanchez, T. Drimalas, B. Fournier, D. Mitchell, and J. Bastien, "Comprehensive damage assessment in concrete affected by different internal swelling reaction (ISR) mechanisms," Cement Concr. Res., vol. 107, pp. 284-303, 2018, http://dx.doi.org/10.1016/j.cemconres.2018.02.017.

[27] M. M. Karthik, J. B. Mander, and S. Hurlebaus, "Simulating behaviour of large reinforced concrete beam-column joints subject to ASR/DEF deterioration and influence of corrosion," Eng. Struct., vol. 222, pp. 111064, 2020, http://dx.doi.org/10.1016/j.engstruct.2020.111064.

[28] M. Thomas, K. Folliard, T. Drimalas, and T. Ramlochan, "Diagnosing delayed ettringite formation in concrete structures," Cement Concr. Res., vol. 38, no. 6, pp. 841-847, 2008, http://dx.doi.org/10.1016/j.cemconres.2008.01.003.

[29] B. Godart and L. Divet, "Lessons learned from structures damaged by delayed ettringite formation and the French prevention strategy," in Proc. 5th Int. Conf. Forensic Eng., France, 2013.

[30] N. P. Hasparyk, S. C. Kuperman, and J. R. Torres Combined attack from ARS and DEF in the foundation," in Proc. 15th Int. Conf. Alkali Aggregate React. Concr., São Paulo, 2016. 
[31] Y. Kawabata, N. Ueda, T. Miura, and S. Multon, "The influence of restraint on the expansion of concrete due to delayed ettringite formation," Cement Concr. Compos., vol. 121, pp. 104062, 2021, http://dx.doi.org/10.1016/j.cemconcomp.2021.104062.

[32] S. K. Melo, "Study of delayed ettringite formation in Portland cement by hydration heat," M.S. thesis, Univ. Fed. Goiás, Goiânia, 2010.

[33] Y. Fu, "Delayed Ettringite Formation in Portland cement products," Ph.D. dissertation, Univ. Ottawa, Ottawa, 1996.

[34] M. Rashidi, A. Paul, J.-Y. Kim, L. J. Jacobs, and K. E. Kurtis, "Insights into delayed ettringite formation damage through acoustic nonlinearity," Cement Concr. Res., vol. 95, pp. 1-8, 2017, http://dx.doi.org/10.1016/j.cemconres.2017.02.004.

[35] S. Bauer, B. Cornell, D. Figursky, T. Ley, J. Miralles, and K. Folliard, Alkali-Silica Reaction and Delayed Ettringite Formation in Concrete: a Literature Review. Report: Project Performed in Cooperation with the Texas Department of Transportation and the Federal Highway Administration. Austin: Center Transp. Res, Univ. Texas, 2006.

[36] B. Kchakech, R. P. Martin, O. O. Metalssi, J. C. Renaud, L. Baron, and F. Toutlemonde, "Effect of temperature and curing duration of early heat treatments on the risk of expansion associated with delayed ettringite formation," in Proc. 15th Int. Conf. Alkali Aggregate React. Concr., São Paulo, 2016.

[37] R. P. Martin, L. F. M. Sanchez, B. Fournier, and F. Toutlemonde, "Evaluation of different techniques for the diagnosis and prognosis of Internal Swelling Reaction (ISR) mechanisms in concrete," Constr. Build. Mater., vol. 156, pp. 956-964, 2017, http://dx.doi.org/10.1016/j.conbuildmat.2017.09.047.

[38] V. H. Nguyen, N. Leklou, and P. Mounanga, "The development of accelerated test method for internal sulfate attack by delayed ettringite formation," Mater. Sci. Forum, vol. 987, pp. 27-32, 2020, http://dx.doi.org/10.4028/www.scientific.net/MSF.987.27.

[39] N. P. Hasparyk, "Investigation of concretes affected by alkali-aggregate reaction and advanced characterization of exuded gel," Ph.D. dissertation, Univ. Fed. Rio Grande do Sul, Porto Alegre, 2005.

[40] J. Sun and Z. Chen, "Influences of limestone powder on the resistance of concretes to the chloride ion penetration and sulfate attack," Powder Technol., vol. 338, pp. 725-733, 2018, http://dx.doi.org/10.1016/j.powtec.2018.07.041.

[41] N. P. Hasparyk, D. Schovanz, and S. C. Kuperman, Instrução Técnica Furnas no GSTE004R0 - Método de Ensaio para a Avaliação do Potencial de Ocorrência da Etringita Tardia (DEF) em Concreto. Ed. Furnas, 2020.

[42] American Society for Testing and Materials, Standard Test Method for Chemical Analysis of Hydraulic Cement, ASTM C 150, 2008.

[43] American Society for Testing and Materials, Standard Test Method for Potential Alkali Reactivity of Aggregates (Mortar-Bar Method), ASTM C 1260, 2018.

[44] Associação Brasileira de Normas Técnicas, Agregados - Reatividade Álcali-Agregado - Parte 1: Guia para Avaliação da Reatividade Potencial e Medidas Preventivas para Uso de Agregados em Concreto, ABNT 15577-1, 2018.

[45] E. Adamopoulou, P. Pipilikaki, M. S. Katsiotis, M. Chaniotakis, and M. Katsioti, "How sulfates and increased temperature affect Delayed ettringite formation (DEF) in white cement mortars," Constr. Build. Mater., vol. 25, no. 8, pp. 3583-3590, 2011, http://dx.doi.org/10.1016/j.conbuildmat.2011.03.051.

[46] K. Ma, G. Long, and Y. Xie, "A real case of steam-cured concrete track slab premature deterioration due to ASR and DEF," Case Stud. Constr. Mater., vol. 6, pp. 63-71, 2017, http://dx.doi.org/10.1016/j.cscm.2016.12.001.

[47] D. G. Batista, "Investigation of concrete deterioration from HPPs by reactions involving aggregates,” M.S. thesis, Univ. Fed. Goiás, Goiânia, 2013.

[48] Z. Zhang, Q. Wang, H. Chen, and Y. Zhou, "Influence of the initial moist curing time on the sulfate attack resistance of concretes with different binders," Constr. Build. Mater., vol. 144, pp. 541-551, 2017, http://dx.doi.org/10.1016/j.conbuildmat.2017.03.235.

[49] A. Blanco, F. Pardo-Bosch, S. Cavalaro, and A. Aguado, "Lessons learned about the diagnosis of pathologies in concrete dams: 30 years of research and practice," Constr. Build. Mater., vol. 197, pp. 356-368, 2019, http://dx.doi.org/10.1016/j.conbuildmat.2018.11.143.

[50] D. Schovanz et al., "Evaluation of delayed ettringite formation through physical, mechanical, and microstructural assays," ACI Mater. J., vol. 118, no. 1, pp. 101-109, 2021, http://dx.doi.org/10.14359/51728282.

[51] B. Godart, "Pathology, assessment and treatment of structures affected by Delayed Ettringite Formation," Struct. Eng. Int., vol. 27, no. 3, pp. 362-369, 2017., http://dx.doi.org/10.2749/101686617X14881932436771.

[52] M. Al Shamaa, S. Lavaud, L. Divet, J. B. Colliat, G. Nahas, and J. M. Torrenti, "Influence of limestone filler and of the size of the aggregates on DEF," Cement Concr. Compos., vol. 71, pp. 175-180, 2016, http://dx.doi.org/10.1016/j.cemconcomp.2016.05.007.

[53] Y. Thiebaut et al., "Effects of stress on concrete expansion due to delayed ettringite formation," Constr. Build. Mater., vol. 183, pp. 626-641, 2018, http://dx.doi.org/10.1016/j.conbuildmat.2018.06.172.

[54] W. H. Price, "Factors influencing concrete strength," J. Proc., vol. 47, pp. 417-432, 1951.

[55] S. K. Melo, N. P. H. Hasparyk, H. Carasek, H. H. Silva, and C. Martins, "Influence of temperature on microstructure of pozzolanic Portland cement paste and the delayed ettringite formation (DEF)," in An. 54 ${ }^{\circ}$ Cong. Bras. Concr., Alagoas, 2012.

[56] Associação Brasileira de Normas Técnicas, Design of Concrete Structures - Procedure, ABNT NBR 6118, 2014.

[57] American Concrete Institute, Building Code Requirements for Structural Concrete, ACI 318-14, 2014. 
[58] E. R. Giannini, "Evaluation of concrete structures affected by alkali-silica reaction and delayed ettringite formation," Ph.D. dissertation, Univ. Texas, Austin, 2012.

[59] N. Smaoui, M.-A. Bérubé, B. Fournier, B. Bissonnette, and B. Durand, "Evaluation of the expansion attained to date by concrete affected by alkali-silica reaction. Part I: experimental study," Can. J. Civ. Eng., vol. 31, no. 5, pp. 826-845, 2004, http://dx.doi.org/10.1139/104-051.

[60] M. O. G. P. Bragança, N. P. Hasparyk, J. L. Bronholo, A. S. Silva, K. F. Portella, and S. C. Kuperman, "Electrochemical impedance spectroscopy and ultrasound for monitoring expansive reactions and their interactions on cement composites," Constr. Build. Mater., vol. 305, pp. 124726, 2021, http://dx.doi.org/10.1016/j.conbuildmat.2021.124726.

[61] A. S. Silva, A. B. Ribeiro, L. Divet, "Prevention of internal sulphate reaction in concrete: long-term results of the effect of mineral additions," in Proc. 16th Int. Conf. Alkali Aggregate React. Concr. Lisboa, vol.1, 2021.

Author contributions: NPH: conceptualization, methodology, SDT and microstructural analyses, writing, global analyses, discussion, supervision, reviewing, funding acquisition; DS: formal analysis, methodology, writing; FT: conceptualization, formal analysis, methodology, writing, supervision; SCK: conceptualization, methodology, supervision, reviewing.

Editors: Bruno Briseghella, Guilherme Aris Parsekian. 